\title{
Simultaneous Effects of Supply and Demand Elasticity with Market Types on Tax Incidence (Graphical Analysis of Perfect Competition, Monopoly and Oligopoly Markets)
}

\author{
Engin Oner \\ Correspondence: Engin Oner, Head of the Public Finance Department, Faculty of Economics and Administrative \\ Sciences, Yuzuncu Yil University, Zeve Campus, 65080, Van, Turkey. E-mail: enginoner@yyu.edu.tr
}

$\begin{array}{ll}\text { Received: December 12, } 2012 & \text { Accepted: December 26, } 2012 \quad \text { Online Published: January 8, } 2013 \\ \text { doi:10.5539/ijef.v5n2p46 } & \text { URL: http://dx.doi.org/10.5539/ijef.v5n2p46 }\end{array}$

\begin{abstract}
The type and character of tax (level of tax rate, narrow or far-reaching scope of tax, being indirect or direct), difference of the market in which activities are being carried out (perfect competition market, monopolist competition, oligopoly, monopoly, etc.), cost conditions (fixed cost conditions, increasing cost conditions, decreasing cost conditions), supply and demand elasticity, conjuncture periods (crisis, welfare, war and interim periods) all affect the extent of incidence. In particular, degrees of elasticity greatly affect the incidence possibility in all market types. Similarly, depending on the elasticity when the demand elasticity is rigid and supply elasticity is high, the incidence becomes easy, but in the opposite situation however, tax incidence through price mechanism becomes harder.
\end{abstract}

Keywords: tax incidence, perfect competition market, oligopoly, monopoly, supply and demand elasticity

JEL: H22, D41, D42, D43, D19

\section{Introduction}

Tax incidence is an event that clarifies which of the legal taxpayer (according to law the person who is charged with paying the tax) or actual taxpayer must finally bear the monetary burden of taxation. In other words, the tax-paying person's (legal taxpayer) transferring of the tax in question to others (to actual taxpayers, tax carriers) through some mechanisms (price mechanism, etc.) is called incidence.

As a result of the reactions of taxpayers against the taxes, at the transfer degree, the burden of tax is on different people (Fisher, 1996: 302; Due \& Friedlaender, 1981: 225).

Tax incidence emerges as a study about who bears the economic burden of the tax (Fullerton \& Metcalf, 2002: 1789).

An incidence case comprises four consecutive stages. These are as follows:

- Tax is paid by the legal taxpayer to the relevant tax office (payment),

- The paid tax has negative pressure on the legal taxpayer (emphasis - psychological pressure)

- The uncomfortable taxpayer has the ability to transfer of the burden of the tax he paid to someone else generally through the price mechanism and depending on supply and demand factors (transfer - switching)

- The bearing of the tax by the last person to whom the shifting was made (settling of tax).

While the statutory taxpayer can bear the whole of the tax, he can shift all of it forward or backward, he can find the possibility to simultaneously and partially shift forward or partially shift backward and he can bear some of the tax burden (Edizdogan, 2007: 200).

When the incidence types are taken into account;

- Depending on the economic situation, the characteristics of the product and the supply-demand elasticity, incidence can be in a forward or backward direction. If tax is passed onto the consumers through the increasing of the prices, then it is the case of forward incidence. In such a case there might be no change in the production prices. On the other hand, if tax is transferred to production factors with no change in consumer prices or if there is a decrease in producer prices, it is the case of backward incidence (Fullerton \& Metcalf, 2002: 1791). 
- In other words, if the statutory taxpayer transfers the tax he paid by increasing the price of the product sold in the market to his customers by totally or partially benefiting from the price mechanism, then this is called forward shifting; in the cases where demand elasticity does not allow the sales price to increase, he can attempt to transfer the tax burden to the ones before him by decreasing the prices of goods (raw materials) he bought or labor costs, and this is called backward shifting.

- Once the statutory taxpayer has transferred the tax he paid to someone else, if this transfer resides with that person, this is called first degree incidence, if that person is also able to shift the tax shifted to himself to some other people, then it is called multiple degree incidence,

- If the shifting of the tax is realized in accordance with the purposes of the law maker, for example when tax laws are prepared, if the legislative organ allows for provisions stipulating that tax to be paid should be borne by the statutory taxpayer or it can be transferred to someone else (Heper, 1987: 148; Heper, 2000: 178), this is called statutory incidence. Benefiting from the price mechanism, a taxpayer's transferring of his tax burden to some other people is called actual incidence. Value Added Tax and Banking and Insurance Transaction Tax are examples of taxes where statutory incidence is realized in our country.

- While limited incidence states that incidence will be in a certain direction and rolled out over certain people or economic factors, limitless incidence means that the tax burden will be spread across the society and eventually the tax burden will be insensible.

- When the structure and effects of the incidence are taken into account, the incidence type that only deals with who pays the tax is called formal incidence, while the incidence where the taxpayer's reaction against the tax, its results and its effects are explored is called effective incidence (Akdogan, 2005: 250; Orhaner, 1992: 160 ).

- Absolute incidence is the effect of an increase in a certain tax on income distribution while differential incidence, when the public spending is assumed to be constant and a tax is replaced with another tax, shows the change in the income distribution (Akdogan, 2005: 250; Orhaner, 1992: 160),

- In the cases where the entrepreneur adds the tax he paid on the intermediate good he had purchased onto price of the good and calculates the profit on the new price and hence he makes profit because of tax, as well as the cases where tax is added to the price in the later stages and is put to taxation again, layered incidence (double incidence - tax pyramidation) emerges.

- Particularly due to the tax imposed on income generating securities and real estate capital factors, a decrease in the value of a taxed good by an amount corresponding to the profit rate of real estate investments prevalent at that date in the market constitutes amortization of the tax (in the case of purchase, it is in favor of the new owner in the form of amortization of the tax amount); an increase in the value of the real estate and the owner indirectly gaining additional capital value when the tax on real estate is lifted is called capitalization of the tax. While some authors exclude amortization and capitalization from incidence, they have been mentioned as types of incidence by some others, as well (Turk, 1992: 216-217; Uluatam, 1991: 239; Erginay, 1990: 118; Orhaner, 1992: 163; Nadaroglu, 1985: 326-331).

\section{Factors Affecting Incidence}

The type and character of tax (level of tax rate, narrow or far-reaching scope of tax, being indirect or direct), difference of the market in which activities are being carried out (perfect competition market, monopolist competition, oligopoly, monopoly, etc.), cost conditions (fixed cost conditions, increasing cost conditions, decreasing cost conditions), supply and demand elasticity, conjuncture periods (crisis, welfare, war and interim periods) all affect the extent of incidence.

Therefore, the factors determining the incidence are comprised of such micro economic factors as the elasticity of supply and demand, the structure of the market, the type and character of the tax, as well as macro economic factors like the conjuncture situation that the economy is in (Sengok, 1993: 42).

Institutional, informational, and behavioral factors may influence tax incidence. Furthermore, there is no accounting in the theoretical literature for the potential influence of the type of market institution on tax incidence. Markets need institutions to function, and these institutions specify how buyers and sellers interact to determine prices and quantities. Different market institutions are known to have different price formation and quantity determination properties; there is no reason to believe a priori that these different properties will not affect the incidence and excess burden of a tax (Cox, Rider \& Sen, 2012: 2).

The final incidence of a tax often cannot be directly observed nor even estimated with absolute objectivity. The subjective selection of economic and behavioral assumptions exerts a heavy influence on the calculated incidence, 
and myriad assumptions are possible (Combs, 2007: 43).

Due to changes in the equilibrium prices and behaviors of the shifters, economic incidence happens to become different from statutory incidence (Fullerton and Metcalf, 2002: 1789).

As a result of the incidence of taxes and depending on elasticity in investment and consumption spending of people and groups, two effects take place. The first one of them is the income effect and it can be defined as a decrease in disposable income due to tax. The second one is called the substitution effect. The substitution effect is that as a result of a relative increase in the price of tax imposed goods, consumption is cut or goods with less tax burden are demanded (Durmus, 2003: 234).

To understand the distributional effects of a tax, it is necessary to know who ultimately bears the burden of the tax. The theory of tax incidence concerns itself with answering this very question, and there may be no more important one in public finance. According to the standard theory, the incidence of a tax in long-run competitive equilibrium has nothing to do with the statutory assignment of the liability to pay tax. Rather, it depends on the relative elasticities of supply and demand; the more inelastic of the two ultimately bears the greater burden of the tax (Cox, Rider \& Sen, 2012: 1).

When the elasticity is taken into consideration, incidence will be easy if the demand elasticity is rigid and supply elasticity is high and elasticity will be hard in the opposite situation. Further elaboration follows:

- Incidence is inversely proportional with demand elasticity and directly proportional with supply elasticity. When the demand elasticity decreases, forward tax incidence gets easier and when the demand elasticity increases, backward incidence becomes easier. On the other hand, when the supply elasticity increases, forward incidence gets easier and when the supply elasticity decreases, backward incidence becomes easier. (Edizdogan \& Celikkkaya, 2010: 185; Erginay, 1990: 121; Dalton, 1961: 38),

- If the demand elasticity is equal to zero, the increase taking place in the indirect taxes will be totally reflected in the market price and because there is not much that the consumers can do against price changes, they will feel forced to buy the good (Odabasi, 2007: 42).

- If the price elasticity of the demand is high, the change in the price will be zero and the increase in the indirect tax will not be reflected in the price in any way. In fact, if the market demand is sensitive against the price changes, sellers will have difficulty in forward shifting the indirect tax and the tax burden will remain totally on their shoulders (Odabasi, 2007: 43).

- If the supply price elasticity is zero, an increase in the indirect tax will not be reflected in the market price in any way and the change in the price will be zero. In cases where the market supply is rigid, whatever the demand elasticity may be, it is the sellers who have to pay the total of the indirect tax. If the supply price elasticity is $+\infty$, an increase in the indirect tax will be completely reflected in the market price and the change in the tax and change in the price will be the same. This situation means complete forward shifting of the tax (Odabasi, 2007: 44).

\section{Incidence with Respect to Market Types and Elasticity}

By taking both the market types and elasticity simultaneously into account, let us see how the incidence occurs on the consumption taxes collected according to quantity and value.

When both the supply and demand in a perfect competition market are assumed to be less elastic (Figure 1); 


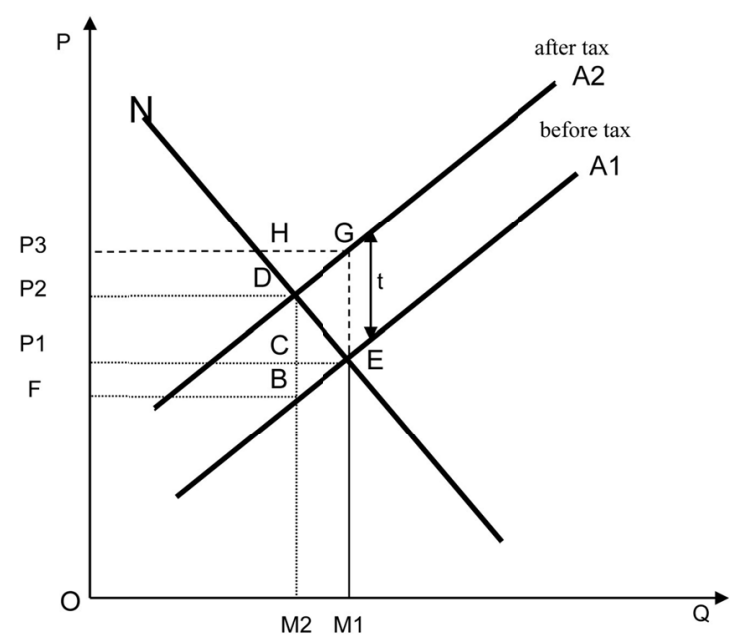

Figure 1. Incidence in the situation where supply and demand are less elastic in a perfect competition market

Point (P1) shows the equilibrium price before a specific tax has been introduced or increased. After the tax at the rate of $(t)$ has been imposed, by increasing the sales price by the tax amount meaning at $(t)$ level, the seller tries to shift the tax burden forward. Therefore, the supply curve shifts upward by $(\mathrm{t})$ amount. The equilibrium point between the new supply curve (A2) and demand curve (N) is (P2) and the sales price corresponding to this is (M2). In such a case, $\left(\mathrm{P}_{1} \mathrm{CDP} 2\right)$ portion of $\left(\mathrm{FBDP}_{2}\right)$ tax revenue is shifted to the buyer, as well. The portion that remains with the seller is (P1CBF) (Turhan, 1997: 378).

In a situation where the demand is completely elastic, let us see the direction of the incidence with the help of Figure 2:

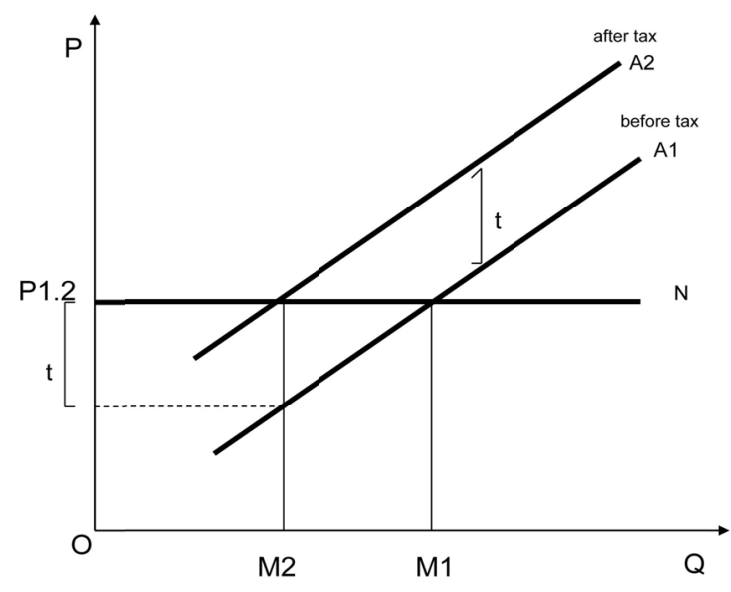

Figure 2. Incidence in a perfect competition market where the demand is elastic

As seen in Figure 2, the (A1) curve shifts in an upward direction by a tax amount which is at (t) level and turns into (A2) curve. Although the new equilibrium price does not change (P1=P2), the amount of demanded goods reduces from (M1) to (M2). Hence, the seller himself has been bearing all of the tax he should pay to the tax office (t.M2), in other words incidence does not occur (Turhan, 1977: 378).

In a situation where the demand is completely rigid (Figure 3), just the opposite situation to the above explanations emerges. 


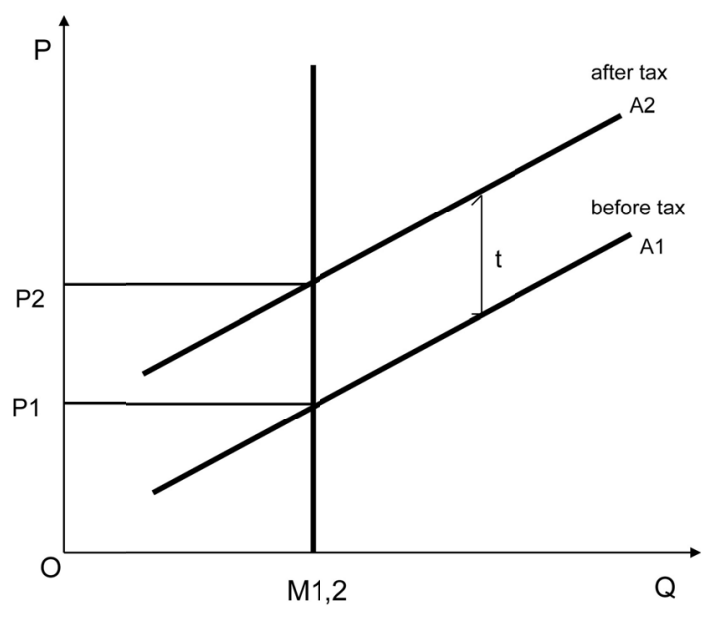

Figure 3. Incidence in a perfect competition market where demand is completely inelastic

As seen in Figure 3, the tax increase is completely shifted to the buyer. The equilibrium price increases by tax rate (t) per piece from $(\mathrm{P} 1)$ to $\left(\mathrm{P}_{2}\right)$. These types of situations can be encountered in the taxation of essential consumption goods (for example: bread, salt, etc.) where demand elasticity is completely rigid (Turhan, 1977: 379).

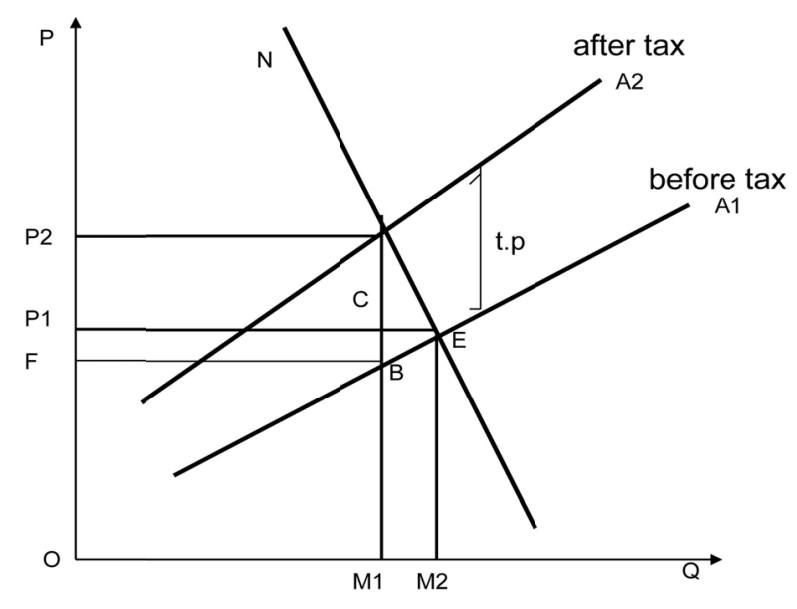

Figure 4. Incidence in the taxes collected according to value

With the help of Figure 4 above it is possible to show that in a market where perfect competition is prevalent, the incidence of a tax collected according to value (ad valorem taxation) would not cause very different problems from a tax collected according to quantity (specific taxation).

From the point of view of their effects on firms and the market, ad valorem sales taxes lead to similar results as specific indirect taxes, both in the short and the long term. The characteristic that distinguishes ad valorem sales taxes from specific sales taxes is that tax is stated as a fraction of taxable value. This situation not only shifts the market supply curve but it also leads to a change in the slope of the market supply curve. In a clearer statement, an increase in ad valorem sales taxes causes both the shifting of the market supply curve to the north-west and decreases the slope of market supply function or increases the slope of market inverse supply function. This means that as a result of an increase in ad valorem sales taxes, supply price elasticity gets more rigid (Bulmus, 1994: 303).

The most salient characteristic that distinguishes Figure 4 from Figure 1 is that the after tax supply curve is more perpendicular compared to the initial supply curve. The reason for this is that the application of the tax rate is not only on quantity but also on the proceeds (price). Because the tax rate amount per piece (t.p) increases in 
absolute terms as the price of the good increases, the supply curve after tax must be in a more perpendicular shape compared to the supply curve before the tax. Therefore, the distance between the two supply curves (A1 and A2) is determined by the value that comes up as a result of the multiplication of the tax rate by the price (t.p) (Turhan, 1997: 380).

In the long term income has been changing, and in principle, it is realized in the form of income increases. In such a case, income elasticity of a good, for example of a luxurious good, becomes high which means that if the good in question is demanded more as the income increases, then the demand curve shifts outward and it makes the possibility of forward incidence relatively easier. Contrarily, with "ordinary" goods (because of negative income elasticity) the course of actions is in the reverse direction (Turhan, 1997: 380).

It is imperative not to think that the conclusions reached for the case of perfect competition are important only for this form of the market. In particular, the fact that elasticity degrees affect incidence possibility to a great extent is also valid for other market forms. For instance, the rule of "the more the demand gets elastic, i.e., the flatter the demand curve is, the harder it will be to shift the tax through the price mechanism" is also valid for a market form where a monopoly exists.

This is because in a monopoly market and in fixed costs conditions the price increase will be less than the total amount of tax, part of the tax will be endured by monopoly profit and profit will decrease to the extent of the hardship of incidence (Edizdogan \& Celikkaya, 2010: 187; A. M. Sharp \& B.F. Sliger, 1970: 225).

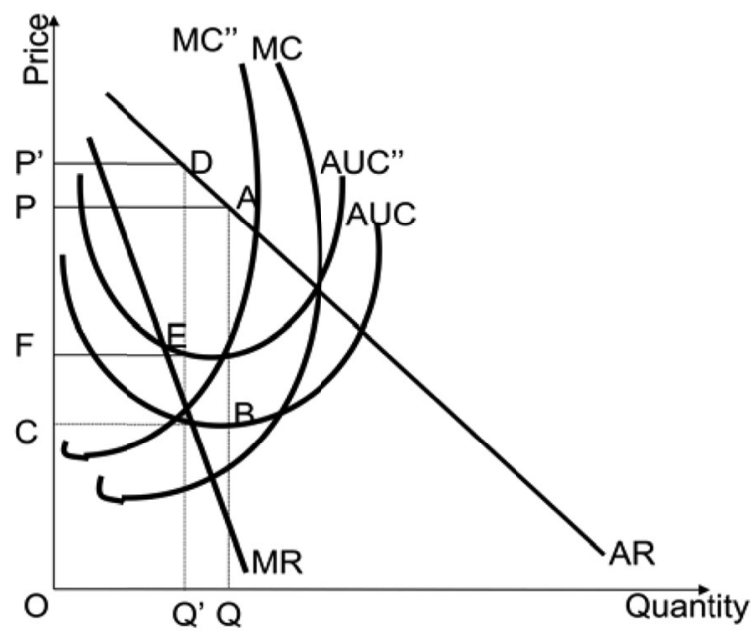

Figure 5. Incidence in a monopoly market

In a monopoly, as it is seen in Figure 5, the equilibrium production level is $0 \mathrm{Q}$ and the equilibrium price is QP. At this point the marginal cost is equal to the marginal income and the profit of the monopoly has reached its peak (PABC).

After imposing a special sales tax per piece, the MC and AUC curves shift upward left and they form MC' and AUC' curves. The new equilibrium point is $0 \mathrm{P} 1$ and the new price is QP'. It is the (PIDEF) rectangle that determines the monopoly profit after tax. Because it is smaller than (PABC) rectangle, the monopoly profit after tax remains at a lower level than the monopoly profit before tax. This means that tax has partly settled on the monopolist and it has partly shifted forward (Nemli, 1979:147). 


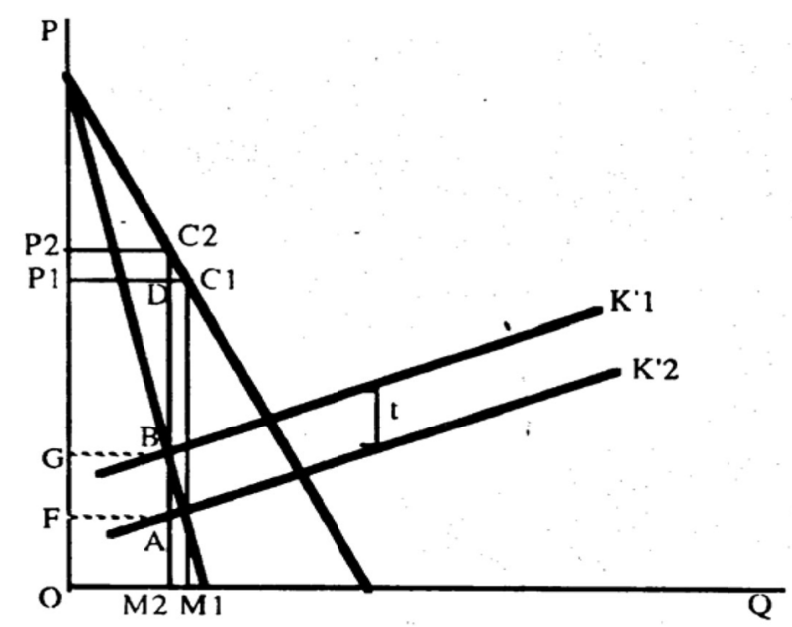

Figure 6. Incidence in a monopoly market when the demand is less elastic

In Figure 6 where demand elasticity is low, imposing or increasing by (t) amount of specific tax causes the marginal cost curve to shift to the left (K'2) and therefore leads to an increase equal to the tax amount in the marginal expenses per piece. The increase in question causes a relatively smaller decrease in the sales amount (from $\mathrm{M}_{1}$ to $\mathrm{M} 2$ ') and a stronger increase in the prices (from P1 to P2). As a result of this, incidence occurs on a relatively large scale. Because $\left[\left(\mathrm{P} 2{ }^{-}{ }^{\mathrm{P}} 1\right) . \mathrm{M}_{2}\right]$, which means $(\mathrm{P} 1 \mathrm{DC} 2 \mathrm{P} 2)$ portion of the new tax in the amount $\left[\mathrm{M}_{2} . \mathrm{t}\right.$ (or FABG)] is being shifted, the remaining portion (FABG - P1DC2P2) is however, borne by the seller (the monopolistic firm) (Turhan, 1997: 382).

In monopoly markets tax incidence in the short and long term is dependent on the monopoly power of the firms. Particularly when there is a tax that affects the costs in monopoly markets, the tax can be shifted by increasing the monopoly price (Heper, 2000: 181).

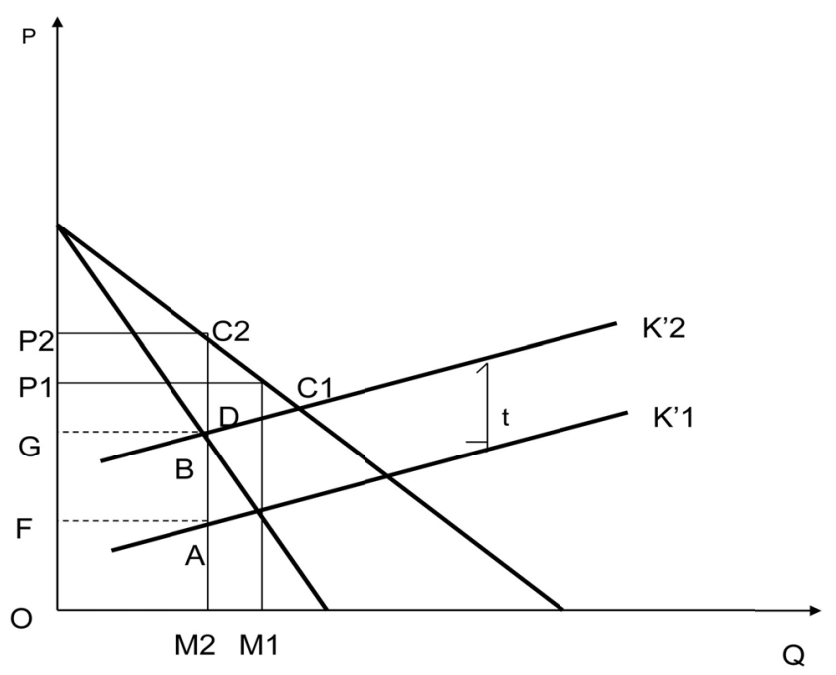

Figure 7. Incidence in a monopoly market where demand is elastic

The situation where demand is elastic is in completely the reverse direction (Figure 7). The increase taking place in the marginal costs due to tax causes a greater decrease in the sales amounts and a lesser increase in prices. As a natural result of this, incidence occurs in a smaller volume ( $\left.\mathrm{P}_{1} \mathrm{DC}_{2} \mathrm{P}_{2}\right)$ (Turhan, 1997: 382).

Because perfect competition and monopoly are two extreme market forms, it is hard to encounter them in real life. Therefore, let us analyze the incidence of a specific tax in an oligopoly market which is more common. As is 
known, the number of firms in this form of market is small. The oligopolist must always take the reactions of his competitors into account in his price policy. This is because a price increase policy of a firm will not be followed by the others and it causes the threat of that firm losing its customers and hence, a great decrease in its circulation. A policy working in the reverse direction, which means a price decrease however, does not give the desired result because it is adopted exactly by competitor firms. Therefore, a preference for price stability emerges as a general tendency in the oligopoly market type (Turhan, 1997: 384).

The small number of firms and comparison probability in an oligopoly market makes it difficult to forecast the amount and direction of the tax incidence (Edizdogan and Celikkaya, 2010: 187). The fact is that a few large firms must establish close relations and parallelism in production - price matters, hence prevalent uncertainty in policies are the main characteristics of an oligopoly market. When special consumption tax per unit is imposed, a decrease occurs in this degree of uncertainty because each enterprise knows clearly that costs increase due to tax in other enterprises, too.

If the demand for the good produced in the industry is not elastic and enterprises have been producing various goods together, each firm can likely add all of the tax to the sales price.

If, before the tax firms have not increased their profits to the maximum level, the efforts for tax incidence draw them closer to this position. However, in order not to draw a reaction from the public and be subject to state intervention, some enterprises refrain from adjusting the production amount and the price in a way to maximize profit. Therefore, depending on the situation, tax can partially or completely shift forward.

In the short term due to such reasons as the fact that the cost per unit increases when the sales decrease or that the demand conditions do not allow for price increases, firms can find it necessary to meet the tax from excess profit (Due \& Friedlaender, 1981: 390).

As a result of tax application in an oligopoly market because each firm guesses that their competitors will increase the prices, as well, prices will increase by the tax amount. If before tax prices have not formed at the optimal profit level, the excuse of tax profits can be rearranged. In the situation where the demand is not elastic, if the firms guess that their competitors will follow them, the probability of shifting the tax to the consumers is high. (Edizdogan, 1981: 46).

In the situation shown in Figure 8, if a specific tax is collected, the marginal cost curve - as in the case earliershifts to the left. In such a case, what is important from the perspective of incidence likelihood is whether or not the marginal cost curve shifting to the left (K') crosses the marginal revenue curve ( $\left.E^{\prime}\right)$ in the dotted (perpendicular) section area or above it.

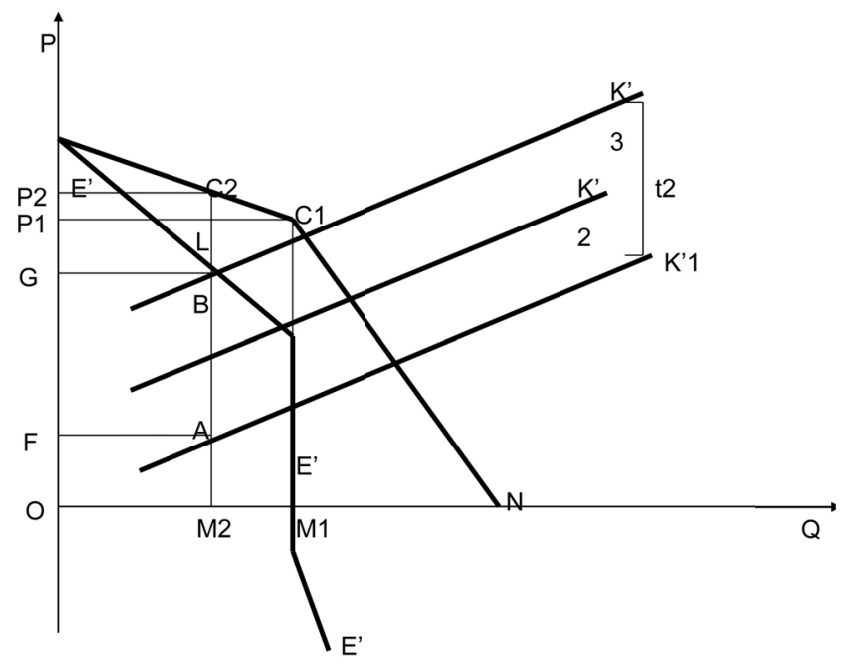

Figure 8. Incidence in an oligopoly market

Because in the first case, meaning in the case when the marginal cost curve $\left(K^{\prime} 2\right)$ crosses the marginal revenue curve $\left(E^{\prime}\right)$ within the perpendicular price area and the production level does not change, the seller must bear all of 
the tax in the (M1.t1) amount and therefore, incidence does not occur. On the other hand, if the tax amount reaches (t2) level, the marginal cost curve shifts from (K'1) to (K'3) and crosses the marginal cost curve (Ei) at point (B). As a result of this, the (P2) price which is higher than (P1) is established. In this way, while the portion of the tax at (p1 DC2P2) height is shifted to the buyer, the difference between (FABG) which is the total of the tax amount and the shifted (P1 DC2P2) is borne by the seller (the oligopolist firm). If the demand had been more rigid at the top of point $\left(\mathrm{C}_{1}\right)$, in other words the demand curve had been more perpendicular, then the buyer would have borne relatively more tax while the seller would have borne less tax. Because in general the demand curve concerning the entire market is more vertical compared to the demand curve of each oligopolist firm, the likelihood of incidence is greater (Turhan, 1997: 385).

\section{Assessment and Conclusion}

Incidence differs with respect to taxes. Although indirect taxes can be more easily shifted than direct taxes, the incidence possibility in itself of the taxes in the character of direct tax can be different.

Incidence analysis attempts to identify who bears the ultimate burden of a given tax. The analysis can be conducted on two levels: first, measurement of the initial direct "impact" of the tax in terms of the share borne by consumers and/or different business sectors; and second, measurement of the ultimate "incidence," frequently represented by translating the initial impacts in terms of their effects on different household income groups (Combs, 2007: 43).

Taxes collected from merchants, manufacturers, farmers and self-employed earners can be shifted less compared to expenditure taxes. Here adding the tax on top of prices is less easy; calculations regarding the incorporation of the tax into the prices are more complex. Despite this, the incidence of tax is possible.

Taxes collected from wages and salaries and revenues as well as the taxes that are not collected from the sale of a good or service are the taxes that can be shifted the least. This is because here there is no customer or buyer to whom the tax can be shifted. Doubtlessly, in theory it cannot be claimed that tax cannot be shifted; if a group of wage-earners have been united within labor unions by going on strike or exerting pressure on employers through their unions, although rarely, they can incorporate the taxes they paid on their wages into the wage increases they obtain and shift them to the employer (Turk, 1992: 218).

Because excise taxes are added to the cost of good or service supplied for sale, they can be easily transferred to buyers. In our country, Banking and Insurance Transactions Tax and Value Added Tax are the taxes that can be easily shifted to consumers. The tax that has been paid by the statutory taxpayer is partially or completely transferred to consumer within the price mechanism. The extent of incidence however, changes with respect to the factors we mentioned earlier affecting the incidence (Orhaner, 1992: 162).

Sales and consumption taxes are stated as inversely increasing rated when they are assumed to be borne by consumers and they are stated as increasing rated when the factor revenues are assumed to be borne by buyers.

In Inheritance and Succession tax there is virtually no possibility of tax incidence. The tax is borne by heirs and the ones in whose favor assets are donated.

In property tax incidence possibility is limited. In general, taxes collected on real estate do not shift and they are borne by the owner. However, if the building or land has been rented out and the economic situation allows for increasing the rents, then incidence can be observed. This means that the tax collected from real estate capital gain can be transferred to tenants when the economic situation allows (Shah \& Whalley, 1991: 539).

In corporate tax, while the possibility of shifting the tax in the medium and short term is low, in the long term and depending on the situation of the firm, the possibility of incidence of tax can increase as much as economic situation allows (Turhan, 1997: 361-394; Akdogan, 2005:257; Nadaroglu, 1985:297; Uluatam, 1991: 202; Kizilyalli, 1969: 97-104; Akkaya, 1993: 147).

From the perspective of incidence of various taxes, the closer the tax is to the supply and demand mechanism, the easier it can be shifted. Taxes collected over expenditures are the taxes that can be shifted the most, as these taxes are the taxes which are the most dependent on the supply and demand mechanism. Expenditure taxes are calculated on cost of the goods sold. It is very easy to add these taxes onto the prices of the goods sold. Here the question encountered is, in the buy-sell chain who among the buyers - the producer, wholesaler, semi-wholesaler, retailer or consumer- will eventually pay the tax. Because forward shifting of the tax is a general tendency, the tax is shifted towards the consumer.

As a conclusion, it can be said that elasticity degrees greatly affect incidence possibility in all market types. Depending on the elasticity, when the demand elasticity is rigid and the supply elasticity is high, incidence is easy, in the opposite situation however, incidence of tax through the price mechanism becomes harder.

\section{References}

Akdoğan, A. (2005). Kamu Maliyesi. Ankara: Gazi Kitabevi. 
Akkaya, Ş. (1993). Kurumlar Vergisinin Yansıması, Maliye Araştırma Merkezi Konferansları. Sayı, 35, 137-148, Retrieved from www.iudergi.com/tr/index.php/iktisatmaliye/article/view/14057

Bulmuş, İ. (1994). Mikroiktisat. Eğitim Yayınları, Ankara.

Combs, S. (2007). Tax Exemptions, \& Tax Incidence, A Message From The Comptroller, Office of The Comptroller, Texas, $\quad$ February, $1-71 . \quad$ Retrieved from http://www.window.state.tx.us/taxinfo/incidence/incidence07/incidence07.pdf

Cox, J. C., Rider, M., \& Sen, A. (2012). tax incidence: do institutions matter? an experimental study, September, 1-29, Retrieved from http://excen.gsu.edu/workingpapers/GSU_EXCEN_WP_2012-17.pdf

Dalton, H. (1961). Principles of Public Finance, Routledge. Kegan Paul Ltd., London.

Durmuş, M. (2003). Maliye Politikaları Teori ve Uygulama. Yaklaşım Yayınları, Ankara.

Edizdoğan, N. (1981). Teoride ve Uygulamada Özel Tüketim Vergileri, Bursa.

Edizdoğan, N. (2007). Kamu Maliyesi, Güncelleştirilmiş 9. Baskı, Ekin Kitapevi, Bursa.

Edizdoğan, N. ve Çelikkaya, A. (2010). Vergilerin Ekonomik Analizi, Dora Yayınları, Mart Bursa.

Erginay, A. (1990). Kamu Maliyesi. Gözden Geçirilmiş ve İşlenmiş 13. Baskı. Savaş Yayınları. Ankara.

Fullerton, D., \& Metcalf, G. E. (2002). Tax İncidence. Handbook of Public Economics, 4, Edited by A.J. Auerbach, \& M. Feldstein, Elsevier Science, B.V. http://dx.doi.org/10.1016/S1573-4420(02)80005-2

Gisher, R. C. (1996). State and Local Public Finance. Irwin Inc.

Heper, F. (1987). Vergi Yükü, Vergi Baskısı ve Yansıma, Kamu Maliyesi-2, Anadolu Üniversitesi, AÖF Yayınları No:13. Ankara, Kasım.

Heper, F. (2000). Vergi Yükü ve Yansıma, Kamu Maliyesi - 2, Anadolu Üniversitesi, AÖF Yayınları No:18. Eskişehir, Ağustos.

John, F. D., \& Friedlaender, A. F. (1981). Government Finance, Economics of the Public Sector, seventh edition. Richard D. Irwin, Inc.

Kızılyallı, H. (1969). Türk Vergi Sisteminin Ekonomik Analizi, Ankara Üniversitesi, Siyasal Bilgiler Fakültesi Yayınları No: 286, Maliye Enstitüsü Yayınları No: 33, Sevinç Matbaası, Ankara.

Nadaroğlu, H. (1985). Kamu Maliyesi Teorisi. Genişletilmiş ve Gözden Geçirilmiş 6. Baskı. Beta Basım Yayım Dağıtım A.Ş., İstanbul.

Nemli, A. (1979). Kamu Maliyesine Giriş. İstanbul Üniversitesi. İktisat Fakültesi. Maliye Enstitüsü Yayın No: 62, İstanbul.

Odabaşı, C. (2007). Vergileme ve Firma Davranışları: Türkiye Otomobil Piyasası, yayınlanmamış Yüksek Lisans Tezi, Gazi Üniversitesi,Sosyal Bilimler Enstitüsü, Ankara.

Orhaner, E. (1992). Kamu Maliyesi. Gazi Üniversitesi. Ekim / Ankara.

Shah, A., \& Whalley, J. (1991). Tax Incidence Analysis of Developing Countries: An Alternative View. The World Bank. Economic Review, 5(3), 535-552. http://dx.doi.org/10.1093/wber/5.3.535

Sharp, A. M., \& Sliger, B. F. (1970). Public Finance, an Introduction to the Study of the Public Economy. Business Publication Inc., Austin, Texas.

Şengök, N. (1993). Vergilerin Mikroekonomik Etkileri, Gazi Üniversitesi Sosyal Bilimler Enstitüsü, Ankara, (Yayımlanmamış Yüksek LisansTezi).

Turhan, S. (1977). Vergi Teorisi. 2. Baskı. İstanbul Üniversitesi. İktisat Fakültesi No: 435, Maliye Enstitüsü No: 57, İstanbul -Kasım.

Türk, İ. (1992). Kamu Maliyesi. Turhan Kitabevi, 1. Baskı. Ankara.

Uluatam, Ö. (1991). Kamu Maliyesi. Genişletilmiş 4. Baskı, Savaş Yayınları, Ankara. 